\title{
Pengembangan Perangkat Pembelajaran Kolaboratif pada Mata Pelajaran Matematika Topik Kubus dan Balok
}

\author{
*Putu Hesti Mardika Astuti ${ }^{1}$, I Gede Margunayasa ${ }^{2}$, I Made Suarjana ${ }^{3}$ \\ 1,2,3 Jurusan Pendidikan Dasar, FIP Universitas Pendidikan Ganesha Singaraja, Indonesia
}

\author{
A R T I C L E I N F O \\ Article history: \\ Received 10 May 2019 \\ Received in revised form \\ 10 June 2019 \\ Accepted 15 July 2019 \\ Available online 29 August \\ 2019 \\ Kata Kunci: \\ matematika, pembelajaran \\ kolaboratif, perangkat \\ pembelajaran. \\ Keywords: \\ mathematic, collaborative \\ learning, learning devices.
}

\begin{abstract}
A B S T R A K
Adapun hasil observasi, dimana perangkat pembelajaran berupa silabus, RPP, dan LKPD yang digunakan guru belum dikembangkan. Penelitian ini bertujuan untuk mengembangkan perangkat pembelajaran kolaboratif pada mata pelajaran matematika topik kubus dan balok siswa kelas V SD yang teruji validitas isinya. Perangkat pembelajaran yang dikembangkan yaitu silabus, RPP, dan LKPD. Penelitian ini merupakan penelitian pengembangan menggunakan model pengembangan ADDIE yang terdiri dari tahap analisis (analyze), tahap perancangan (design), tahap pengembangan (development), tahap implementasi (implementation), dan tahap evaluasi (evaluation). Mengingat keterbatasan waktu, penelitian ini dilaksanakan hanya sampai tahap pengembangan (development). Subjek penelitian ini yaitu perangkat pembelajaran. Teknik pengumpulan data menggunakan metode kuesioner dengan instrumen rating scale berupa lembar penilaian perangkat pembelajaran. Analisis data yang digunakan yaitu
\end{abstract} analisis data deskriptif kualitatif dan analisis data deskriptif kuantitatif. Hasil pengembangan menunjukkan bahwa rata-rata skor validitas silabus yaitu 4,52, rata-rata skor validitas RPP secara keseluruhan yaitu 4,47, rata-rata skor validitas LKPD secara keseluruhan yaitu 4,54. Dengan demikian perangkat pembelajaran kolaboratif pada mata pelajaran matematika topik kubus dan balok siswa kelas V SD yang teruji validitas isinya secara keseluruhan memiliki kualifikasi sangat baik.

\section{A B S T R A C T}

This study aimed to develop collaborative learning tools on mathematics subjects such as cubes and beams of fifth grade elementary school students whose content validity tested. Learning tools developed are syllabus, lesson plan, and students' worksheet. This research was a development research using the ADDIE model which consists of the analysis phase, design, development, implementation, and evaluation. This research carried out only to development. The subject of this research was the learning device. The technique of collecting data was the questionnaire method with a rating scale instrument in the form of a learning device assessment sheet. Data analyzed by descriptive qualitative data analysis and quantitative descriptive data analysis. The results of the development showed that the average syllabus validity score was 4.52, the average score of the validity of the lesson plan as a whole was 4.47, the average score of the overall students worksheet validity was 4.54. Yhe collaborative learning tool on the subject matter of cube and beam mathematics in fifth grade of elementary school has very good qualifications.

\section{Pendahuluan}

Pembelajaran abad 21 memiliki pengaruh terhadap kemajuan teknologi informasi dan komunikasi (TIK) di berbagai aspek kehidupan, termasuk di bidang pendidikan. Pengaruh IPTEK di bidang pendidikan abad 21 mengharuskan setiap siswa memiliki keterampilan dalam proses pembelajaran yang disebut dengan keterampilan 4C yaitu communication, critical thinking, collaboration, dan creativity (Nuraziza, $\mathrm{R}$. dan Irma, 2018). Pengembangan keterampilan dengan aspek 4C dilaksanakan untuk membekali siswa kemampuan dalam mengatasi permasalahan kehidupan sehari-hari. Keterampilan 4C pada pembelajaran dapat diberikan melalui berbagai disiplin ilmu (Rahmawati, 2017). Salah satu disiplin ilmu yang

Copyright (c) Universitas Pendidikan Ganesha. All rights reserved. 
mendasari perkembangan teknologi serta memiliki peran penting dalam memajukan daya pikir manusia adalah ilmu matematika.

Matematika adalah "ilmu pasti yang dalam proses pembelajarannya sangat banyak terdapat rumus, angka, dan simbol-simbol matematis" (Agustyaningrum, N. dan Helen, 2016:1). Matematika sebagai salah satu disiplin ilmu menuntut pemahaman dan ketentuan berlatih siswa dalam proses pembelajaran (Siagian, 2012). Pembelajaran metematika sangat berkaitan dengan konsep-konsep abstrak yang dikembangkan berdasarkan alasan-alasan yang logis (Supardi, 2012). Konsep abstrak dalam matematika dimaksudkan sebagai suatu aktivitas mental untuk memahami arti dari struktur-struktur, hubunganhubungan, dan simbol-simbol, kemudian menetapkan konsep-konsep yang dihasilkan ke situasi yang nyata sehingga menyebabkan suatu perubahan tingkah laku.

Matematika sebagai salah satu disiplin ilmu diberikan sejak usia sekolah dasar dengan tujuan dapat meningkatkan kemampuan berpikir dan memberikan kontribusi dalam penyelesaian masalah sehari-hari (Susanto, 2013). Pembekalan pembelajaran matematika untuk anak sekolah dasar tentu menjadi strategi khusus dalam melaksanakan pembelajaran untuk mendukung keberhasilan dalam menghadapi tantangan dimasa depan. Pembelajaran matematika di sekolah dasar membekali siswa berbagai kemampuan seperti: kemampuan berpikir logis, analitis, sistematis kritis dan kreatif serta kemampuan bekerjasama (Japa dan Suarjana , 2015). Pembelajaran matematika abad 21 dengan menerapkan aspek 4C didukung oleh kemampuan guru dalam merencanakan dan melaksanakan pembelajaran (Amir, 2014). Matematika perlu dibelajarkan kepada semua siswa mulai dari tingkat sekolah dasar (SD) untuk membekali siswa berbagai kemampuan seperti kemampuan berpikir logis, analitis, kritis, dan kreatif, serta kemampuan bekerjasama (Japa dan Suarjana, 2015). Secara umum, tujuan pembelajaran matematika di sekolah dasar adalah agar siswa mampu dan terampil menggunakan matematika. Secara khusus tujuan pembelajaran matematika di sekolah dasar yaitu: (1) memahami konsep matematika, menjelaskan keterkaitan antar konsep serta mengaplikasikan konsep atau algoritma; (2) menggunakan penalaran pada pola dan sifat, melakukan manipulasi matematika dalam generalisasi, menyusun bukti, atau menjelaskan gagasan dan pernyataan matematika; (3) memecahkan masalah dengan cara memahami masalah, merancang masalah dengan kemampuan memahami masalah, merancang model matematika, menyelesaikan model, dan menafsirkan solusi yang diperoleh; (4) mengkomunikasikan gagasan dengan simbol, diagram, tabel atau media lain untuk memperjelas keadaan masalah; (5) memiliki sikap menghargai penggunaan matematika dalam kehidupan sehari-hari (Depdiknas dalam Japa dan Suarjana, 2015).

Kurikulum 2013 mengamanatkan siswa untuk mampu dan memiliki bekal sikap, pengetahuan, dan keterampilan yang cukup untuk penyelesaian masalah dalam kehidupan, sehingga guru harus mampu merancang perangkat pembelajaran yang mampu memberikan pengalaman belajar kepada siswa (Rahmadi, 2015). Pengalaman belajar dalam proses pembelajaran dapat diberikan melalui aspek pencapaian kompetensi yang terdiri dari beberapa aspek yaitu aspek pengetahuan, sikap, dan keterampilan (Kosasih, 2014). Aspek pengetahuan atau kognitif meliputi pengetahuan faktual, pengetahuan konseptual, pengetahuan prosedural, dan pengetahuan metakognitif (Qadar, 2015). Aspek afektif ditunjukkan oleh perilaku yang berurusan dengan hal-hal emosional seperti perasaan, nilai-nilai, motivasi, dan sikap yang diukur dengan tujuan untuk mendapatkan informasi yang akurat mengenai tingkat pencapaian, partisipasi dan kemampuan serta karakteristik siswa (Qadar, 2015). Aspek psikomotor berkaitan dengan keterampilan (skill) atau kemampuan bertindak setelah seseorang menerima pengalaman belajar (Nurbudiyani, 2013). Pencapaian aspek kompetensi tentu merupakan strategi bagi guru untuk merencanakan pembelajaran. Perencanaan pembelajaran dipersiapkan oleh guru sebelum mengajar dan terurai di dalam perangkat pembelajaran.

Perangkat pembelajaran merupakan "segala alat dan bahan yang digunakan guru untuk melakukan proses pembelajaran" (Chodijah, 2012:10). Perangkat pembelajaran digunakan guru sebagai pedoman dalam melaksanakan proses pembelajaran di kelas sehingga proses pembelajaran dapat berlangsung lebih terarah menuju kompetensi yang dituju (Azka, dan Santoso, 2015). Perangkat pembelajaran "memuat kegiatan-kegiatan yang mencerminkan proses bagaimana siswa memahami atau memeroleh produk ilmiah" (Listyawati, 2012:63). Kegiatan yang dimuat pada perangkat pembelajaran membantu siswa untuk memahami materi yang dipelajari melalui langkah-langkah pembelajaran yang telah dirancang untuk menghasilkan suatu produk yang bermanfaat untuk ketercapaian tujuan pembelajaran. Berdasarkan uraian tersebut, dalam konteks penelitian ini dapat disintesis bahwa perangkat pembelajaran adalah segala alat dan bahan yang memuat kegiatan proses pembelajaran dapat berlangsung lebih terarah menuju kompetensi yang dituju. Perangkat pembelajaran yang dibuat harus disesuaikan dengan tingkat pengetahuan dan pengalaman siswa, untuk mencapai tujuan pembelajaran yang diharapkan.

Perangkat pembelajaran yang dimaksud yaitu silabus, RPP, dan LKPD. Silabus digunakan sebagai acuan penyusunan kerangka pembelajaran untuk setiap bahan kajian mata pelajaran. Silabus paling sedikit memuat: identitas mata pelajaran, identitas sekolah, kelas, kompetensi inti, kompetensi dasar, 
tema, materi pokok, pembelajaran, penilaian, alokasi waktu, dan sumber belajar. Peranan silabus dalam perangkat pembelajaran sangat penting, silabus dikembangkan berdasarkan Standar Kompetensi Lulusan dan Standar Isi (Peraturan Menteri Pendidikan dan Kebudayaan Nomor 22 Tahun 2016). RPP adalah rencana kegiatan pembelajaran tatap muka untuk satu pertemuan atau lebih yang perancangan dan pembuatannya berdasarkan pada silabus yang ada untuk mencapai kompetensi dasar. Komponen RPP terdiri dari: identitas sekolah, identitas mata pelajaran atau tema/subtema, kelas/semester, materi pokok, alokasi waktu, tujuan pembelajaran, kompetensi dasar dan indikator pencapaian kompetensi, materi pembelajaran, metode pembelajaran, media pembelajaran, sumber belajar, langkah-langkah pembelajaran, dan penilaian hasil pembelajaran (Peraturan Menteri Pendidikan dan Kebudayaan Nomor 22 Tahun 2016). LKPD atau nama lain dari Lembar Kerja Siswa (LKS) adalah "lembaran berisi tugas yang harus dikerjakan oleh peserta didik" (Chodijah, 2012:13). LKPD tidak hanya berisikan soal-soal yang menuntut siswa untuk menjawabnya tetapi juga berisi konsep-konsep penting terkait materi pembelajaran (Rahmadani, 2012). LKPD merupakan stimulus atau bimbingan guru dalam pembelajaran yang disajikan secara tertulis sehingga dalam penulisannya perlu memperhatikan media grafis sebagai media visual untuk menarik perhatian siswa (Fannie, 2014). LKPD memuat komponen-komponen meliputi: judul LKPD, identitas siswa, kompetensi dasar, tujuan pembelajaran, dan isi LKPD (Astuti, 2013). Berdasarkan uraian tersebut, dapat disintesis bahwa LKPD merupakan stimulus atau bimbingan guru dalam bentuk lembaran berisi konsep materi pembelajaran dan tugas-tugas yang dikerjakan oleh siswa sebagai panduan dalam proses pembelajaran.

Perangkat pembelajaran dirancang dan dibuat oleh guru sesuai dengan karakteristik, pengetahuan, dan tingkat kebutuhan siswa untuk mencapai tujuan pembelajaran yang diharapkan. Perancangan perangkat pembelajaran yang baik sesuai dengan komponen perangkat pembelajaran yang terdapat pada Permendikbud Nomor 22 Tahun 2016 dan bercermin pada pelaksanaan pembelajaran abad ke-21 yang mengharuskan pembelajaran dapat diterapkan melalui aspek 4C (communication, critical thinking, collaboration, dan creativity) (Nuraziza, 2018). Perancangan perangkat pembelajaran yang berkaitan dengan penerapan pembelajaran kolaboratif mampu memudahkan tercapinya tujuan pembelajaran serta dapat meningkatkan kemampuan siswa (Herawati, 2018).

Hasil observasi pembelajaran matematika yang dilaksanakan pada 10 Januari 2019 di sekolah dasar Gugus IX Kecamatan Buleleng diketahui bahwa pada bagian pendahuluan guru tidak mengaitkan pengetahuan awal siswa dengan materi pembelajaran yang dipelajari sebelumnya, guru langsung menyampaikan topik materi yang dibelajarkan. Pada kegiatan inti pembelajaran, siswa hanya mendengarkan uraian serta melihat contoh-contoh yang diberikan guru, siswa hanya diam ketika disuruh bertanya dan siswa juga diam ketika guru bertanya. Siswa tidak dilatih untuk melakukan diskusi, siswa hanya mengerjakan tugas yang mampu dikerjakannya tanpa mencoba melakukan kolaborasi dengan teman lainnya. Pada kegiatan penutup, guru tidak menyimpulkan materi pembelajaran yang diberikan dan tidak melakukan evaluasi terhadap materi pembelajaran. Proses pembelajaran tersebut menunjukkan bahwa pembelajaran masih berpusat pada guru (teacher centered), sehingga berdampak pada rendahnya kompetensi pengetahuan khususnya pada mata pelajaran matematika khususnya topik kubus dan balok. Salah satu materi penting yang diajarkan dalam pembelajaran kubus dan balok di sekolah dasar adalah volume (Feriana, dan Ratu, 2016). Suatu bangun ruang, secara umum bisa memiliki unsur-unsur sebagai berikut: (1) sisi, merupakan bagian bidang yang membatasi bagian dalam dan bagian luar bangun ruang, (2) rusuk, adalah garis yang merupakan perpotongan dua sisi pada bangun ruang, (3) titik sudut, adalah titik yang merupakan perpotongan tiga rusuk atau lebih, (4) diagonal sisi, adalah ruas garis yang menghubungkan dua titik sudut yang berhadapan pada setiap bidang sisi, (5) bidang diagonal, adalah bagian bidang yang dapat dibentuk melalui diagonal sisi yang sejajar, (6) diagonal ruang, adalah ruas garis yang menghubungkan dua titik sudut yang berhadapan dan dua titik sudut tersebut tidak terletak dalam satu bidang (Japa,dkk., 2016).

Hasil wawancara yang dilaksanakan pada 10 Januari 2019 dengan beberapa guru kelas V di sekolah dasar Gugus IX Kecamatan Buleleng, didapat informasi bahwa perangkat pembelajaran silabus yang digunakan guru tidak sesuai dengan komponen silabus yang ada pada Permendikbud Nomor 22 Tahun 2016. Silabus yang digunakan hanya terfokus pada komponen silabus yang telah ada tanpa melakukan inovasi terhadap indikator dan kegiatan pembelajaran. Penyusunan RPP yang dilakukan oleh guru tidak dirancang dengan baik, guru hanya mengandalkan RPP yang didapat ketika mengikuti pelaksanaan Kelompok Kerja Guru (KKG), sehingga perumusan indikator dan tujuan pembelajaran yang dibuat tidak sesuai dengan situasi dan kondisi sekolah. Indikator yang ada pada RPP tidak sesuai dengan karakteristik siswa, dan tujuan pembelajaran pada RPP tidak mencerminkan aspek ABCD (Audience, Behavior, Condition, Degre). LKPD sebagai bahan ajar yang menunjang terlaksananya pembelajaran belum tersedia dengan baik. Guru hanya menugaskan siswa untuk mengerjakan soal-soal yang terdapat pada buku ajar tanpa menyusun sendiri LKPD sesuai dengan materi ajar secara inovatif dan kolaboratif. Berdasarkan 
permasalahan perangkat pembelajaran yang ditemukan, menunjukkan bahwa perangkat pembelajaran berupa silabus, RPP, dan LKPD yang digunakan guru belum dikembangkan. Hasil studi dokumen yang dilaksanakan pada 15 Januari 2019 diperoleh data nilai Ulangan Akhir Semester (UAS) pada kompetensi pengetahuan matematika siswa kelas V di Gugus IX Kecamatan Buleleng berbeda di semua sekolah, ada yang memiliki kompetensi pengetahuan tinggi dan ada pula yang memiliki kompetensi pengetahuan rendah. Hasil studi dokumen yang dilaksanakan pada tanggal 15 Januari 2019 diperoleh data nilai ulangan akhir semester (UAS) pada kompetensi pengetahuan matematika siswa kelas V di Gugus IX Kecamatan Buleleng berbeda di semua sekolah, ada yang memiliki kompetensi pengetahuan tinggi dan ada pula yang memiliki kompetensi pengetahuan rendah. Hal ini dapat dibuktikan dari 282 siswa kelas V di Gugus IX Kecamatan Buleleng persentase pencapaian KKM nilai kompetensi pengetahuan matematika siswa yang mencapai KKM sebanyak 49,30\% dan siswa yang tidak mencapai KKM sebanyak 50,71\%. Hasil tersebut menunjukkan bahwa nilai matematika siswa SD di Gugus IX Kecamatan Buleleng pada aspek pengetahuan masih rendah.

Berdasarkan permasalahan yang ditemukan salah satu upaya yang dapat dilakukan untuk mengatasi permasalahan yaitu perlu dikembangkannya perangkat pembelajaran kolaboratif. Pembelajaran kolaboratif menekankan pada "filosofi pembelajaran kolaborasi adalah bekerja, membangun pembelajaran, mengubah, serta meningkatkan bersama" (Abizar, 2017:107).

Pembelajaran kolaboratif membentuk siswa menjadi beberapa kelompok kecil dengan beranggotakan 4 orang secara heterogen sesuai jenis kelamin. Pembelajaran kolaboratif pada kelompok kecil dapat dilakukan dengan penataan kelas berbentuk huruf U (model seminar) dan disesuaikan dengan situasi dan kondisi sekolah. Didasari oleh penataan kelas berbentuk huruf U merupakan syarat dasar agar semua siswa dapat ikut berpartisipasi dalam pembelajaran kolaboratif tanpa terkecuali (Sato, 2014). Materi pelajaran pada pembelajaran kolaboratif dilakukan dengan dua tugas, yaitu tugas bersama (sharing task) adalah tugas individu melalui kolaboratif dalam kelompok-kelompok kecil yang mengandung materi dasar untuk mencapai tujuan pembelajaran dan tugas melompat (jumping task) yang mengandung masalah untuk meningkatkan kemampuan siswa (Fatimah, 2018). Pembelajaran kolaboratif pada pengembangan perangkat pembelajaran matematika diharapkan dapat membantu siswa meningkatkan interaksi dan kerjasama dengan teman sebaya, membantu siswa meningkatkan kemampuan pemahaman konsep dalam memecahkan permasalahan yang dihadapi melalui hubungan saling belajar, membantu siswa mengaitkan materi pelajaran dengan kehidupan sehari-hari sehingga dapat menumbuhkan semangat belajar dan pembelajaran lebih bermakna bagi siswa yang berdampak pada ketercapaian hasil belajar yang maksimal.

Mengingat pengembangan perangkat pembelajaran sangat penting, maka dilakukan penelitian pengembangan dengan tujuan untuk mengembangkan perangkat pembelajaran kolaboratif pada mata pelajaran matematika topik kubus dan balok siswa kelas V SD yang teruji validitas isinya.

\section{Metode}

Jenis penelitian yang dilakukan adalah penelitian pengembangan (research development). Penelitian pengembangan adalah kegiatan untuk mengembangkan dan menghasilkan produk yang digunakan dalam pendidikan atau pembelajaran (Tegeh, dkk., 2014). Produk yang dikembangkan pada penelitian ini berupa perangkat pembelajaran kolaboratif meliputi silabus, RPP dan LKPD pada mata pelajaran matematika topik kubus dan balok untuk siswa kelas V SD.

Model penelitian pengembangan yang digunakan pada penelitian ini adalah rancangan model pengembangan ADDIE (Analyze, Design, Development, Implementation, Evaluation). Model ADDIE merupakan "salah satu model desain pembelajaran sistematik" (Tegeh, dkk., 2014). Model ADDIE ini terdiri atas tahap analisis (analiyze), tahap perancangan (design), tahap pengembangan (development), tahap implementasi (implementation), dan tahap evaluasi (evaluation). Pada penelitian pengembangan ini, tahapan model ADDIE dilaksanakan sampai tahap pengembangan (development) dikarenakan keterbatasan waktu penelitian. Pemilihan model ini didasari atas pertimbangan bahwa model ini disusun secara terprogram dengan urutan-urutan kegiatan yang sistematis dalam upaya pemecahan masalah belajar yang berkaitan dengan kebutuhan dan karakteristik pebelajar (Tegeh, dkk., 2014). Model ADDIE memberi peluang untuk melakukan evaluasi terhadap aktivitas pengembangan pada setiap tahap. Hal ini berdampak positif terhadap kualitas produk pengembangan.

Subyek penelitian pengembangan ini yaitu perangkat pembelajaran. Perangkat pembelajaran yang dimaksud ialah silabus, RPP, dan LKPD. Analisis data yang digunakan dalam penelitian ini yaitu data kualitatif dan kuantitatif. Metode pengumpulan data pada penelitian ini menggunakan metode kuesioner. Metode kuesioner pada penelitian ini digunakan untuk mengetahui validasi perangkat pembelajaran yang dikembangkan melalui penilaian yang dilakukan oleh ahli pembelajaran, ahli matematika, dan guru. 
Instrumen yang digunakan pada penelitian ini yaitu rating scale berupa lembar penilaian perangkat pembelajaran. Lembar penilaian yang dibuat memuat skor 1 dengan kategori sangat kurang, skor 2 dengan kategori kurang, skor 3 dengan kategori cukup, skor 4 dengan kategori baik, dan skor 5 dengan kategori sangat baik. Instrumen yang telah disusun selanjutnya dinilai oleh Judges atau pakar yang ahli dalam bidangnya.

Teknik analisis data yang digunakan adalah adalah teknik analisis deskriptif kualitatif dan teknik analisis deskriptif kuantitatif. Analisis data kualitatif pada penelitian ini digunakan untuk mengolah data hasil review ahli matematika, ahli pembelajaran dan guru. Analisis data ini dilakukan dengan mengelompokkan informasi dari data kualitatif berupa masukan, saran, dan komentar perbaikan yang terdapat pada angket. Hasil analisis ini kemudian digunakan untuk merevisi produk yang dikembangkan. Analisis deskriptif kuantitatif pada penelitian ini digunakan untuk mengolah data validitas perangkat pembelajaran meliputi: silabus, RPP, dan LKPD yang diperoleh melalui kuesioner dalam bentuk skor. Analisis deskriptif kuantitaif dilakukan dengan mengitung mean atau rata-rata nilai setiap produk perangkat pembelajaran setelah dilakukan penilaian/uji coba.

\section{Hasil dan Pembahasan}

Penelitian pengembangan perangkat pembelajaran kolaboratif meliputi silabus, RPP, dan LKPD pada topik kubus dan balok untuk siswa kelas V SD di Gugus IX Kecamatan Buleleng dilaksanakan dari tanggal 15 April sampai 29 April 2019. Subyek dalam penelitian ini yaitu perangkat pembelajaran. Hasil dari penelitian ini berupa perangkat pembelajaran kolaboratif meliputi silabus, RPP, dan LKPD pada mata pelajaran matematika topik kubus dan balok untuk siswa kelas V SD dengan kualifikasi sangat baik. Hasil validasi didapat dari pelaksanaan uji instrumen melalui judges dan uji produk melalui ahli pembelajaran, ahli matematika, dan guru. Analisis data perangkat pembelajaran dilakukan dengan mencari ratarata/mean dari data yang telah ada. Hasil analisis silabus didapatkan bahwa 1 dan 2 rata-rata skor validitasnya yaitu 5. Komponen 3 dan 9 rata-rata skor yang diperoleh yaitu 4,5. Komponen 5, 6, 8, 11, dan 12 rata-rata skor validitasnya yaitu 4,25. Komponen 4 dan 10 memeroleh rata-rata skor tertinggi yaitu 4,75. Secara keseluruhan dari komponen silabus yang ada, rata-rata skor validitas silabus yaitu 4,52 berada pada rentang skor $4,01<X \leq 5,01$. Hal ini menunjukkan bahwa silabus yang dikembangkan secara keseluruhan berada pada kualifikasi "sangat baik". Hasil analisis RPP dengan rata-rata skor masingmasing RPP dari RPP 1 sampai RPP 6 dapat dilihat pada Gambar 1.

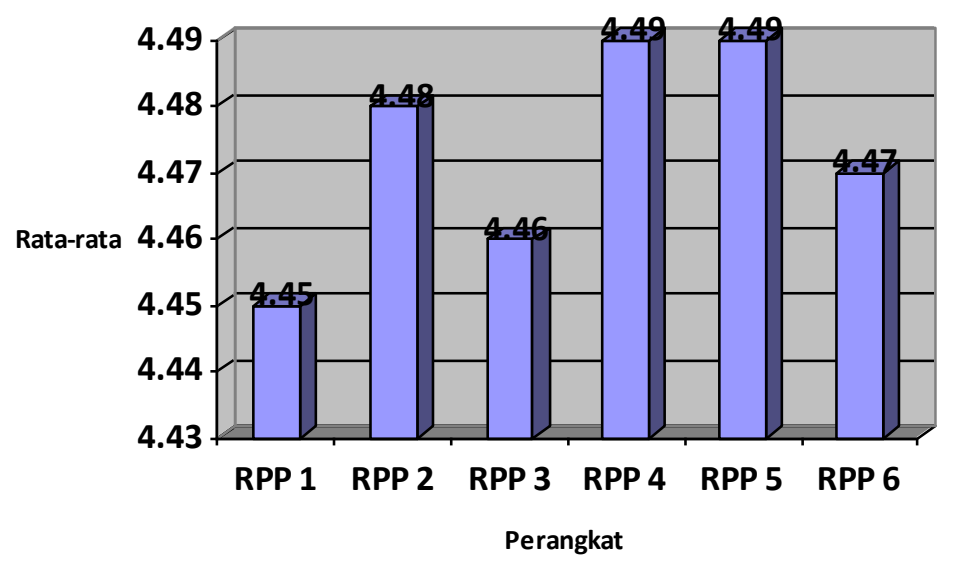

Gambar 1.

Grafik Rata-rata Skor Validitas RPP

Berdasarkan pada Gambar 1 diketahui bahwa bahwa rata-rata skor validitas RPP 1 secara keseluruhan yaitu 4,45 berada pada rentang skor 4,01<X $\leq 5,01$ dengan kualifikasi sangat baik; RPP 2 rata-rata skor validitas secara keseluruhan yaitu 4,48 berada pada rentang skor 4,01<X $\leq 5,01$ dengan kualifikasi sangat baik; RPP 3 secara keseluruhan memeroleh skor rata-rata validitas 4,46 berada pada rentang skor 4,01<X 5,01 dengan kualifikasi sangat baik; RPP 4 dan RPP 5 memeroleh rata-rata skor validitas yang sama yaitu 4,49 berada pada rentang skor $4,01<\mathrm{X} \leq 5,01$ dengan kualifikasi sangat baik; RPP 6 rata-rata skor validitasnya yaitu 4,47 berada pada rentang skor 4,01<X 5,01 dengan kualifikasi sangat baik. Secara keseluruhan rata-rata skor RPP 1 sampai RPP 6 yaitu 4,47 berada pada rentang skor $4,01<X \leq 5,01$. Hal ini menunjukkan bahwa komponen tiap RPP maupun komponen keseluruhan RPP 
berada pada kualifikasi "sangat baik". Rata-rata skor masing-masing LKPD 1, LKPD 2, LKPD 3, LKPD 4 , LKPD 5, dan LKPD 6 disajikan pada Gambar 2.

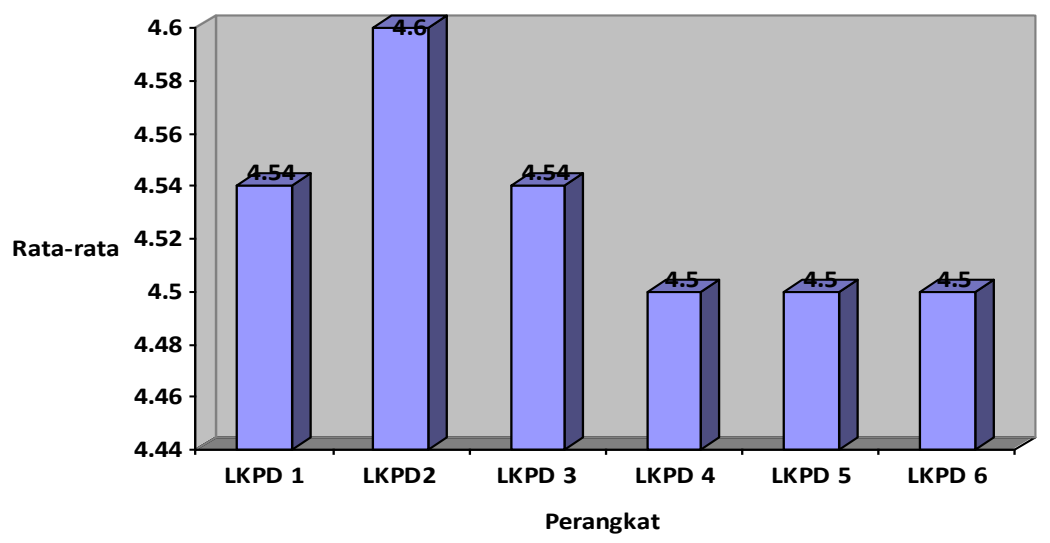

Gambar 2.

Grafik Rata-rata Skor Validitas LKPD

Berdasarkan data pada Gambar 2 diketahui bahwa total rata-rata skor validitas LKPD 1 dan 3 yaitu 4,54 berada pada rentang skor 4,01<X $\leq 5,01$ dengan kualifikasi sangat baik. LKPD 2 total rata-rata skor validitas yaitu 4,60 berada pada rentang skor $4,01<X \leq 5,01$ dengan kualifikasi sangat baik. LKPD 4, 5, dan 6 memiliki total rata-rata skor validitas yang sama yaitu masing-masing 4,50 berada pada rentang skor $4,01<X \leq 5,01$ dengan kualifikasi sangat baik. Secara keseluruhan total rata-rata skor validitas LKPD yang ada yaitu 4,54 berada pada rentang skor 4,01<X $\leq 5,01$ dengan kualifikasi sangat baik. Hal ini menunjukkan bahwa LKPD yang dikembangkan dapat dikualifikasikan "sangat baik".

Pengembangan perangkat pembelajaran kolaboratif berupa silabus, RPP, dan LKPD dilakukan dengan menggunakan model pengembangan ADDIE yang meliputi tahap analisis (analysis), tahap perancangan (design), dan tahap pengembangan (development). Adapun penjabaran dari pengembangan produk yang dilakukan sesuai dengan tahapan pengembangan model ADDIE yaitu: tahap analisis (analyze) penelitian pengembangan ini dilaksanakan melalui beberapa kegiatan yaitu analisis kebutuhan, analisis karakteristik siswa, dan analisis kurikulum.

Analisis kebutuhan dilakukan melalui kegiatan observasi dan wawancara terkait dengan perangkat pembelajaran yang digunakan. Perangkat pembelajaran merupakan segala alat dan bahan yang digunakan guru untuk melaksanakan proses pembelajaran (Chodijah, 2012). Hasil analisis kebutuhan diketahui bahwa perangkat pembelajaran berupa silabus yang digunakan guru tidak sesuai dengan komponen silabus yang ada pada Permendikbud Nomor 22 Tahun 2016. Silabus yang digunakan hanya terfokus pada komponen silabus yang telah ada tanpa melakukan inovasi terhadap indikator dan kegiatan pembelajaran. Penyusunan RPP tidak dirancang oleh guru dengan baik, guru hanya mengandalkan RPP yang didapat ketika mengikuti pelaksanaan Kelompok Kerja Guru (KKG), sehingga perumusan indikator dan tujuan pembelajaran yang dibuat tidak sesuai dengan situasi dan kondisi sekolah. Indikator yang ada pada RPP tidak sesuai dengan karakteristik siswa, dan tujuan pembelajaran pada RPP tidak mencerminkan aspek ABCD (Audience, Behavior, Condition, Degre). LKPD sebagai bahan ajar yang menunjang terlaksananya pembelajaran belum tersedia dengan baik, guru hanya menugaskan siswa untuk mengerjakan soal-soal yang terdapat pada buku ajar tanpa menyusun sendiri LKPD sesuai dengan materi ajar secara inovatif dan kolaboratif. Rahmadani (2012) mempertegas bahwa LKPD tidak hanya berisikan soal-soal yang menuntut siswa untuk menjawabnya tetapi juga berisi konsep-konsep penting terkait materi pembelajaran. Oleh karena itu penyusunan LKPD sangat diperlukan untuk menunjang pelaksanaan proses pembelajaran. Berdasarkan permasalahan yang ditemukan menunjukkan bahwa perangkat pembelajaran berupa silabus, RPP, dan LKPD yang digunakan guru belum dikembangkan.

Berdasarkan analisis karakteristik siswa melalui kegiatan observasi diketahui bahwa pada proses pembelajaran siswa jarang dilatih untuk melaksanakan pembelajaran secara kolaboratif yang dapat meningkatkan kerjasama dan hubungan saling belajar dalam proses pembelajaran sehingga kompetensi pengetahuan siswa masih bersifat heterogen, artinya siswa ada yang memiliki tingkat pengetahuan tinggi, sedang, dan rendah. Hal tersebut dipertegas oleh Sato (2014) yaitu pembelajaran kolaboratif dilaksanakan dengan membentuk siswa menjadi beberapa kelompok kecil dengan penataan kelas 
berbentuk huruf $U$ yang disesuaikan dengan situasi dan kondisi sekolah sebagai syarat dasar agar semua siswa dapat ikut berpartisipasi dalam pembelajaran kolaboratif tanpa terkecuali untuk menciptakan hubungan saling belajar sehingga memperoleh manfaat dalam memahami materi pembelajaran. Analisis kurikulum dilaksanakan dengan menganalisis kompetensi dasar berdasarkan Permendikbud Nomor 24 Tahun 2016 sehingga mampu dirumuskan indikator ketercapaian kompetensi sesuai dengan materi dan topik yang dibahas, pada penelitian ini materi dan topik yang dibahas yaitu kubus dan balok. Berdasarkan tiga analisis yang telah dilakukan, maka dipandang perlu untuk melaksanakan pengembangan perangkat pembelajaran kolaboratif pada mata pelajaran matematika topik kubus dan balok untuk meningkatkan kerjasama dan hubungan saling belajar antar siswa dalam proses pembelajaran.

Tahap perancangan (design) dilakukan perencaan perangkat pembelajaran kolaboratif berupa silabus, RPP, dan LKPD mata pelajaran matematika topik kubus dan balok. Penyusunan silabus dilakukan dengan beberapa komponen yaitu: (1) sampul silabus, (2) identitas mata pelajaran, (3) identitas sekolah, (4) kompetensi inti, (5) kompetensi dasar, (6) topik kubus dan balok, (7) materi pokok, (8) kegiatan pembelajaran kolaboratif, (9) penilaian, (10) alokasi waktu, dan (11) sumber belajar. Penyusunan RPP dilaksanakan dengan merancang enam buah RPP yang masing-masing RPP memuat beberapa komponen, yaitu: (1) sampul RPP, (2) identitas RPP, (3) kompetensi dasar, (4) indikator pencapaian kompetensi, (5) tujuan pembelajaran, (6) materi pembelajaran, (7) pendekatan, model, dan metode pembelajaran, (8) media pembelajaran berupa LKPD, (9) sumber belajar, (10) langkah-langkah pembelajaran sesuai langkah pembelajaran model kolaboratif, dan (11) penilaian hasil belajar. Penyusunan LKPD disesuiakan dengan panduan pengembangan bahan ajar Depdiknas 2008 yang terdiri dari komponen yaitu: (1) sampul LKPD, (2) identitas LKPD yang memuat tanggal kegiatan, mata pelajaran, kelas/semester dan topik materi yang dibahas, (3) tujuan LKPD, (4) petunjuk kerja, (5) materi LKPD, (6) kegiatan siswa meliputi sharing task dan jumping task, (7) alokasi waktu yang disesuaikan dengan kegiatan pembelajaran pada LKPD, dan (8) simpulan yang memuat rangkuman pokok dalam LKPD. Desain LKPD dirancang semenarik mungkin sesuai dengan karakteristik siswa guna meningkatkan semangat dan motivasinya dalam belajar.

Tahap pengembangan (development) perangkat pembelajaran kolaboratif meliputi silabus, RPP, dan LKPD dilaksanakan sesuai dengan rancangan yang telah dibuat. Tahap pengembangan dilakukan dengan melaksanakan uji instrumen perangkat pembelajaran untuk memperoleh validasi dari pakar (judges). Setelah instrumen perangkat pembelajaran dikatakan valid, kemudian dilaksanakan uji produk perangkat pembelajaran kolaboratif meliputi silabus, RPP, dan LKPD kepada para ahli (ahli matematika dan ahli pembelajaran) dan guru kelas V di Gugus IX Kecamatan Buleleng. Setelah mendapatkan penilaian dari para ahli dan guru kemudian dilakukan revisi produk dan analisis hasil uji produk. Analisis produk perangkat pembelajaran kolaboratif berupa silabus, RPP, dan LKPD dilakukan dengan menggunakan bantuan Microsoft Excel untuk mencari rata-rata/mean dari masing-masing komponen perangkat pembelajaran kolaboratif berupa silabus, RPP, dan LKPD. Untuk mengetahui kualifikasi perangkat pembelajaran yang dikembangkan selanjutnya hasil analisis disesuaikan dengan Penilaian Acuan Patokan (PAP) Skala Lima untuk memberikan kriteria terhadap hasil rata-rata yang telah didapat.

Berdasarkan hasil uji produk terhadap perangkat pembelajaran kolaboratif berupa silabus, RPP, dan LKPD diperoleh temuan penelitian yaitu perangkat pembelajaran kolaboratif berupa silabus dikembangkan berdasarkan pedoman Permendikbud Nomor 22 Tahun 2016 memiliki rata-rata skor penilaian 4,52 berada pada kualifikasi sangat baik. RPP yang dikembangkan berpedoman pada Permendikbud Nomor 22 Tahun 2016, tujuan pembelajaran pada RPP sudah mencerminkan aspek ABCD (Audience, Behavior, Condition, Degree), RPP yang dikembangkan sebanyak 6 RPP secara keseluruhan memiliki rata-rata skor penilaian 4,47 berada pada kualifikasi sangat baik. LKPD yang dikembangkan berpedoman pada Panduan Pengembangan Bahan Ajar Depdiknas 2008 secara keseluruhan memeroleh rata-rata skor validitas 4,54 dengan kualifikasi sangat baik. Hal ini menunjukkan bahwa perangkat pembelajaran kolaboratif yang dikembangkan secara langsung sudah memenuhi validasi dan berada pada kualifikasi sangat baik, sehingga layak untuk diimplementasikan. Penelitian ini sesuai dengan penelitian dari Listyawati (2012) dalam penelitiannya menemukan bahwa perangkat pembelajaran yang dikembangkan dengan baik sesuai karakteristik siswa dapat digunakan dengan hasil baik dan dapat meningkatkan kemampuan siswa. Santoso (2013) juga membuktikan bahwa penerapan pembelajaran kolaboratif dalam proses pembelajaran dapat membantu siswa meningkatkan hasil belajar yang lebih baik.

Tinjauan mengenai perangkat pembelajaran berupa silabus, RPP, dan LKPD yang dikembangkan didasarkan pada hasil rata-rata skor validasi silabus, RPP, dan LKPD yang dilakukan oleh ahli dan guru. Dilihat dari hasil validasi ahli dan guru terhadap perangkat pembelajaran berupa silabus, RPP, dan LKPD pada mata pelajaran matematika topik kubus dan balok secara keseluruhan berada pada rentang skor $4,01<\mathrm{X} \leq 5,01$ dengan kualifikasi sangat baik. Perangkat pembelajaran yang baik adalah perangkat pembelajaran yang penyusunannya sesuai Permendikbud Nomor 22 Tahun 2016. 
Berdasarkan hasil analisis dan pembahasan hasil penelitian yang telah dijabarkan, maka dapat diketahui bahwa implikasi penelitian pengembangan perangkat pembelajaran kolaboratif berupa silabus, RPP, dan LKPD pada mata pelajaran matematika topik kubus dan balok yaitu perangkat pembelajaran kolaboratif merupakan perangkat pembelajaran yang baru, sehingga dalam proses penyusunannya diperlukan pemahaman dan perencanaan yang mendalam untuk mencapai tujuan pembelajaran yang maksimal.

Pembentukan kelompok secara heterogen pada pembelajaran kolaboratif memerlukan penanganan yang lebih mendalam agar pembelajaran dapat berjalan dengan baik sesuai yang diharapkan, pembentukan kelompok belajar pada pembelajaran kolaboratif sangat diharapkan adanya penilaian yang bersifat obyektif untuk masing-masing individu demi terciptanya suasana belajar yang nyaman bagi siswa. Pelaksanaan pembelajaran kolaboratif terdiri dari dua tugas yaitu sharing task dan jumping task yang mengakibatkan proses pembelajaran memerlukan waktu yang cukup lama, sehingga untuk menyiasati hal tersebut dapat dilaksanakan dengan mengurangi jumlah soal (sharing task dan jumping task) yang terdapat pada masing-masing tugas yang diberikan dan disesuikan dengan kemampuan siswa.

\section{Simpulan dan Saran}

Berdasarkan hasil penelitian dan pembahasan, maka dapat disimpulkan bahwa perangkat pembelajaran kolaboratif yang teruji validitas isinya dapat dilihat dari rata-rata skor validitas silabus yaitu 4,52 dengan kualifikasi sangat baik. RPP secara keseluruhan memiliki rata-rata skor validitas yaitu 4,47 dengan kualifikasi sangat baik. LKPD secara keseluruhan memiliki rata-rata skor validitas yaitu 4,54 dengan kualifikasi sangat baik. Dengan demikian perangkat pembelajaran kolaboratif pada mata pelajaran matematika topik kubus dan balok siswa kelas V SD yang teruji validitas isinya secara keseluruhan memiliki kualifikasi sangat baik.

Saran disampaikan berdasarkan penelitian yang telah dilakukan yaitu: (1) kepada guru, diharapkan dapat menggunakan perangkat pembelajaran kolaboratif pada mata pelajaran matematika topik kubus dan balok yang dikembangkan, selain itu guru juga diharapkan dapat menggunakan model pembelajaran kolaboratif untuk menyusun perangkat pembelajaran pada matapelajaran lain sehingga dapat meningkatkan kualitas perangkat pembelajaran.; (2) kepada kepala sekolah, diharapkan dapat memfasilitasi pengadaan perangkat pembelajaran yang digunakan guru dalam proses pembelajaran sebagai kelengkapan administrasi sekolah. (3) kepada peneliti lain, diharapkan dapat melanjutkan penelitian ini sampai tahap evaluasi melalui penelitian eksperimen. Selain itu, peneliti lain juga dapat mengembangkan perangkat pembelajaran kolaboratif berupa silabus, RPP, dan LKPD pada mata pelajaran lain.

\section{Daftar Rujukan}

Abizar, H. (2017). Buku Master Lesson Study. Yogyakarta: DIVA Press.

Agustyaningrum, N. dan Helen, T. S. (2016). Pengaruh Penggunaan Media Pembelajaran Mind Mapping Terhadap Prestasi Belajar Matematika Siswa Kelas VII SMP Tunas Baru Jin-Seung Batam Tahun Ajaran 2014/2015. Jurnal Phytagoras, 5(1), 32-37.

Amir, A. (2014). Pembelajaran Matematika SD dengan Menggunakan Media Manipulatif. Jurnal Forum Pedagogik, 1(1), 72-89.

Astuti,Y. dan Setiawan, B. (2013). Pengembangan Lembar Kerja Siswa (LKS) Berbasis Pendeka 7 tan Inkuiri Terbimbing dalam Pembelajaran Kooperatif Pada Materi Kalor. Jurnal Pendidikan IPA Indonesia, 2(1), 88-92.

Azka, R. dan Rusgianto, H. S. (2015). Pengembangan Perangkat Pembelajaran Kalkulus Untuk Mencapai Ketuntasan dan Kemandirian Belajar Siswa. Jurnal Riset Pendidikan Matematika, 2(1), 78-91.

Chodijah, S., dkk. (2012). Pengembangan Perangkat Pembelajaran Fisika Menggunakan Model Guided Inquiry yang Dilengkapi Penilaian Portofolio Pada Materi Gerak Melingkar. Jurnal Penelitian Pembelajaran Fisika, 1(1), 1-19.

Fannie, R. D. dan R. (2014). Pengembangan Lembar Kerja Siswa Berbasis Predict, Observe, Explain (POE) pada Materi Program Linear Kelas XII SMA. Jurnal Sainmatika, 8(1), 96-109.

Fatimah, I., dkk. (2018). Didactical Design Based on Sharing and Jumping Tasks for Senior High School Chemistry Learning. Journal of Physics: Conference Series, 1013(1), 1-7.

Feriana, O. dan Ratu, I. I. P. (2016). Desain Pembelajaran Volume Kubus dan Balok Menggunakan Filing 
dan Packing di Kelas V. Jurnal Pendidikan, 46(2), 149-163.

Herawati, A., dkk. (2018). Pengembangan Media Pembelajaran Bangun Ruang Berbasis Discovery Learning dengan Construct 2 dalam Meningngkatkan Kemampuan Pemecahan Masalah Matematika. Jurnal Ilmiah Sekolah Dasar, 2(4), 396-403.

Japa, I G N., dkk. (2016). Buku Ajar Pendidikan Matematika II. Singaraja: Universitas Pendidikan Ganesha.

Japa, I. G. N. dan I. M. S. (2015). Buku Ajar Pendidikan Matematika I. Singaraja: Universitas Pendidikan Ganesha.

Kosasih. (2014). Strategi Belajar dan Pembelajaran Implementasi Kurikulum 2013. Bandung: Yerama Widya.

Listyawati, M. (2012). Pengembangan Perangkat Pembelajaran IPA Terpadu di SMP. Journal of Innovative Science Education, 1(1), 61-69.

Nuraziza, R. dan Irma, R. S. (2018). Menggali Keterampilan Creative Problem Solving yang dimiliki siswa SMP melalui Pembelajaran IPA Berbasis STEM. Jurnal Wahana Pendidikan Fisika, 3(1), 55-61.

Nurbudiyani, I. (2013). Pelaksanaan Pengukuran Ranah Kognitif, Afektif dan Psikomotor Pada Mata Pelajaran IPS Kelas III SD Muhammadyah Palangkaraya. Anterior Jurnal, 13(1), 88-93.

Peraturan Menteri Pendidikan dan Kebudayaan Nomor 22 Tahun 2016 tentang Standar Proses Pendidikan Dasar dan Menengah Kementrian Pendidikan dan Kebudayaan. (n.d.). Jakarta: Depdikbud.

Qadar, R., dkk. (2015). Mengakses Aspek Afektif dan Kognitif pada Pembelajaran Optika dengan Pendekatan Demonstrasi Interaktif. Jurnal Inovasi Dan Pembelajaran Fisika, 2(1), 1-11.

Rahmadani, A., dkk. (2012). Penggunaan Lembar Kerja Siswa yang Dilengkapi Mind Map dalam Pembelajaran Matematika. Jurnal Pendidikan Matematika, 1(1), 30-34.

Rahmadi, F. (2015). Pengembangan Perangkat Pembelajaran Berbasis Pemecahan Masalah Berorientasi pada Kemampuan Penalaran dan Komunikasi Matematika. Jurnal Pendidikan Matematika Raflesia, $10(2), 137-145$.

Rahmawati, S. (2017). Pengembangan Indikator 4 C'S yang selaras dengan Kurikulum 2013 pada Mata Pelajaran Matematika SMP/MTs Kelas VIII Semester I. Jurnal Kadikma, 8(3), 21-30.

Sato, M. (2014). Mereformasi Sekolah Konsep dan Praktek Komunitas Belajar. Tokyo: Japan International Cooperation Agency.

Siagian, R. E. F. (2012). Pengaruh Minat dan Kebiasaan Belajar Siswa terhadap Prestasi Belajar Matematika. Jurnal Formatif, 2(2), 122-131.

Supardi U.S. (2012). Pengaruh Pembelajaran Matematika Realistik Terhadap Hasil Belajar Matematika Ditinjau Dari Motivasi Belajar. Cakrawala Pendidikan, (2).

Susanto, A. (2013). Teori Belajar dan Pembelajaran di Sekolah Dasar. Jakarta: Prenamedia Group.

Tegeh, I M., dkk. (2014). Model Penelitian Pengembangan. Yogyakarta: PT Graha Ilmu. 